\title{
Marketing of Ginger in Aurangabad District of Maharashtra
}

\author{
S. E. Shinde*, R. D. Shelke and G. M. Bodakhe \\ Department of Agricultural Economics, College Agriculture, Latur, India \\ *Corresponding author
}

\begin{tabular}{|c|c|}
\hline & A B S T R A C T \\
\hline Keywords & \multirow{4}{*}{$\begin{array}{l}\text { The study was conducted in the year } 2019-2020 \text { to study the "Marketing } \\
\text { of Ginger in Aurangabad District of Maharashtra" It revealed that, } \\
\text { producer's share in consumer's rupee varied from channel to channel which } \\
\text { was highest in channel-II } 98.48 \text { per cent, channel-I } 98.43 \text { per cent, and } \\
\text { channel-III } 97.39 \text { per cent respectively. The price spread in channel-I Rs. } \\
930 \text {, channel-II Rs.530 and channel-III Rs. } 420 \text {, when it was sold directly } \\
\text { to the wholesaler, Price spread was lower in channel-III as compare to } \\
\text { channel-I and channel-II, it indicates that channel-III best for to sold ginger. }\end{array}$} \\
\hline $\begin{array}{l}\text { Marketing channel, } \\
\text { Market margin and } \\
\text { price spread }\end{array}$ & \\
\hline Article Info & \\
\hline $\begin{array}{l}\text { Accepted: } \\
\text { 07 November } 2020 \\
\text { Available Online: } \\
10 \text { December } 2020\end{array}$ & \\
\hline
\end{tabular}

\section{Introduction}

Spices constitute an important group of Agricultural commodities which were used for flavoring and main ingredients for any tasty food. People have used these plants since earliest times. No other commodity has played more pivotal role in development of modern civilization, exploration and commerce. India is called bowl of spices. Traders are attracted from far corners of the world to India by the aroma and flavor of the spices. The trade of spices is one of the oldest and at one time one of the most important forms of Commerce. The scientific name of ginger is Zingiber officinale. It belongs to Zingiberaceae family. Native from south eastern Asia. The plant also known as shringavera. Ginger is herbaceous perennial crop and it's propagated through rhizomes. The rhizomes put forth erect, leafy stems, 30$90 \mathrm{~cm}$ in height. The base of the leaves sheathe the stem. The leaves are dark green, $15-20 \mathrm{~cm}$ long, narrow, lanceolate and with a prominent midrib. The flowers are small, yellowish, speckled each with a purple speckled lip and born on spike.

\section{Materials and Methods}

The study was based on both primary and secondary data. Primary data were collected through personal interview method from farmers, with the help of well-structured and 
pretested questionnaire exclusively designed for the study. Data were collected from farmers, village traders, wholesalers and retailers, about the price spread, labour charges, transportation costs, commission charges, other charges if any and also the price received by them by personal interview method with the help of pretested interview schedule and pertaining for the year 20192020. Aurangabad market purposively selected because most of the ginger produce from the study area are marketed in that market.

\section{Results and Discussion}

\section{Major marketing channel in the study area}

In the studied area there are three major marketing channel are in use which are shown in table 1. From the table it is evident that channel-III was the most common channel used by the farmers Channel-III. About 38.76 per cent of their marketed surplus was transacted through channel-III and channel- I 37.01 per cent Followed by channel-II 24.22 per cent of the total marketed surplus. The production sold in channel-I, channel-II, and channel-III was 3961, 2592 and 4148 quintals of total produce respectively. The highest production sold in channel-III followed by channel-I and channel-II respectively.

\section{Production, retention and marketed surplus of Ginger marketing}

The detail of total production, marketable surplus and marketed surplus of ginger for the sample farmers is shown in table 2. The study revealed that the average yield was 132.21 quintals on 0.64 hectares and retention for seed purpose 13.32 quintal which constituted 10.07 per cent of total produce. The results revealed that quantity of ginger as 44.01, 28.8 and 46.08 quintals were marketed through channel-I, channel-II, and channel-III. Thus total marketed surplus of ginger was 33.28, 21.78 , and 34.85 per cent respectively.

\section{Marketing cost of ginger incurred by} different intermediaries

Estimation of marketing provides information which us to identify the reason for high marketing costs and possible way to reduce them.

\section{Marketing cost of ginger incurred by producer}

Item wise per quintal cost of marketing of ginger incurred by producer in different channels was calculated and presented in table 3 . The result revealed that marketing, cost incurred by the producer was the highest with Rs.135.5 per quintal in channel- III followed by Rs. 74 in channel-II and Rs. 70.5 per quintal in channel-I of the total marketing cost incurred by producer. In regards to proportionate share of expenditure on individual items in channel-I cost of transportation charges was highest which was Rs.40/qtl among the all items and contributes (56.73) per cent of total cost. Closely followed by labour charges Rs. 12/qtl contributes (17.02) per cent, packing charges Rs.10/qtl (14.18) per cent, losses in ginger Rs. 8/qtl (11.34) and weighing charges Rs.0.50/qtl contributes (0.70) per cent of the total marketing cost of ginger.

In channel-II proportion on expenditure highest also on transportation which was Rs.42/qtl contributes (56.75) per cent, followed by labour charges 13/qtl (17.56) per cent, packing charges Rs.10/qtl i.e. (13.51) per cent, losses in marketing of gingerRs.8.5/qtl means (11.48) per cent and weighing charges Rs.0.50/qtl contributes (0.67) per cent total marketing cost of ginger. Labour charges was highest in channel-II as compared to channel-I. 
Table.1 Major marketing channels identified in the study area

\begin{tabular}{|c|c|c|c|}
\hline Sr.no. & Channels & $\begin{array}{l}\text { Total produce } \\
\text { sold }(q)\end{array}$ & $\begin{array}{c}\text { Per cent } \\
(\%)\end{array}$ \\
\hline 1. & Channel-I (Producer-Village trader-Retailer-Consumer) & 3961 & 37.01 \\
\hline 2. & Channel-II (Producer-Village trader-Retailer-Consumer) & 2592 & 24.22 \\
\hline \multirow[t]{2}{*}{3.} & Channel-III (Producer-Wholesaler- Retailer-Consumer) & 4148 & 38.76 \\
\hline & Total & 10701 & 100 \\
\hline
\end{tabular}

Table.2 Production, Retention and marketed surplus of ginger (qt/ha)

\begin{tabular}{|l|l|c|c|}
\hline Sr. no. & Particulars & Standards & Percentage \\
\hline 1. & Ginger farm (ha) & 0.64 & - \\
\hline 2. & Ginger Production (q) & 132.21 & 100 \\
\hline 3. & Retention of fresh fingers for seed purpose+ & $100)$ & \\
\hline & Home consumption (q) & 13.32 & 10.07 \\
\hline 4. & Marketed surplus in Channel-I & $(10.07)$ & \\
\hline 5. & (Producer- Village trader-Retailer-Consumer) & 44.01 & 33.28 \\
\hline 6. & (Parketed surplus in Channel- II & $(33.28)$ & \\
\hline 7. & Marketed surplus in Channel- III & 28.8 & 21.78 \\
& (Producer-Wholesaler- Retailer-Consumer) & $(21.78)$ & \\
\hline
\end{tabular}

Table.3 Marketing cost incurred by producer (Rs/qtl)

\begin{tabular}{|c|c|c|c|c|}
\hline Sr. No. & Particular & Channel-I & Channel-II & Channel-III \\
\hline 1. & Labour charges & $\begin{array}{c}12 \\
(17.02)\end{array}$ & $\begin{array}{c}13 \\
(17.56)\end{array}$ & $\begin{array}{c}14 \\
(10.33)\end{array}$ \\
\hline 2. & Transportation charges & $\begin{array}{c}40 \\
(56.73)\end{array}$ & $\begin{array}{c}42 \\
(56.75)\end{array}$ & $\begin{array}{c}45 \\
(33.21)\end{array}$ \\
\hline 3. & Weighing charges & $\begin{array}{c}0.50 \\
(0.70)\end{array}$ & $\begin{array}{c}0.50 \\
(0.67)\end{array}$ & $\begin{array}{c}0.50 \\
(0.36)\end{array}$ \\
\hline 4. & Packing charges & $\begin{array}{c}10 \\
(14.18)\end{array}$ & $\begin{array}{c}10 \\
(13.51)\end{array}$ & $\begin{array}{c}12 \\
(8.85)\end{array}$ \\
\hline 5. & Losses & $\begin{array}{c}8 \\
(11.34)\end{array}$ & $\begin{array}{c}8.5 \\
(11.48)\end{array}$ & $\begin{array}{c}9 \\
(6.64)\end{array}$ \\
\hline 6. & Commission charges & - & - & $\begin{array}{c}50 \\
(36.90)\end{array}$ \\
\hline 7. & Market fee & - & - & $\begin{array}{c}5 \\
(3.69)\end{array}$ \\
\hline \multicolumn{2}{|c|}{ Total cost incurred by producer } & $\begin{array}{l}70.5 \\
(100)\end{array}$ & $\begin{array}{r}74 \\
(100)\end{array}$ & $\begin{array}{l}135.5 \\
(100)\end{array}$ \\
\hline
\end{tabular}


Table.4 Marketing cost incurred by village trader (Rs/qtl)

\begin{tabular}{|l|l|c|c|}
\hline Sr. No. & Particular & Channel-I & Channel- II \\
\hline 1. & Labour charges & 13 & 14 \\
& & $(19.83)$ & $(20.74)$ \\
\hline 2. & License charges & 0.15 & 0.15 \\
& & $(0.22)$ & $(0.22)$ \\
\hline 3. & Transportation charges & 30 & 32 \\
& & $(45.76)$ & $(47.40)$ \\
\hline 4. & Storage & 12 & 10 \\
& & $(18.30)$ & $(14.81)$ \\
\hline 5. & Losses & 10 & 10.5 \\
& & $(15.25)$ & $(15.55)$ \\
\hline 6. & Weighing charges & 0.40 & $(0.59)$ \\
\hline
\end{tabular}

Table.5 Marketing cost incurred by wholesaler (Rs/qtl)

\begin{tabular}{|l|l|c|c|}
\hline Sr. no. & Particular & Channel-II & Channel -III \\
\hline $\mathbf{1 .}$ & Labour charges & 16 & 17 \\
& & $(21.58)$ & $(20.70)$ \\
\hline 2. & License charges & 0.20 & 0.20 \\
& & $(0.26)$ & $(0.24)$ \\
\hline 3. & Shop tax & 0.50 & 0.50 \\
& & $(0.67)$ & $(0.60)$ \\
\hline 4. & Transportation charges & 35 & 40 \\
& & $(47.22)$ & $(48.70)$ \\
\hline 5. & Electric charges & 0.42 & 0.42 \\
& & $(0.56)$ & $(0.51)$ \\
\hline 6. & Market fee & 10 & 10 \\
& & $(13.49)$ & $(12.17)$ \\
\hline 7. & Losses & 12 & $(17.04)$ \\
\hline
\end{tabular}


Table.6 Per quintal Marketing cost, Market margin and price spread of ginger (Rs/qtl)

\begin{tabular}{|c|c|c|c|c|}
\hline Sr. No. & Particular & Channel-I & Channel-II & Channel-III \\
\hline & $\begin{array}{l}\text { Net price received by producer ( producer } \\
\text { Share in consumer rupee) }\end{array}$ & $\begin{array}{l}4429.5 \\
(98.43)\end{array}$ & $\begin{array}{c}4826 \\
(98.48)\end{array}$ & $\begin{array}{l}5064.5 \\
(97.39)\end{array}$ \\
\hline 1. & Price received by producer & $\begin{array}{c}4500 \\
(94.73)\end{array}$ & $\begin{array}{c}4900 \\
(92.36)\end{array}$ & $\begin{array}{l}5200 \\
(92.36)\end{array}$ \\
\hline 2. & Cost incurred by producer & $\begin{array}{l}70.5 \\
(1.56)\end{array}$ & $\begin{array}{c}74 \\
(1.51)\end{array}$ & $\begin{array}{l}135.5 \\
(2.6)\end{array}$ \\
\hline 3. & Price received by village trader & $\begin{array}{l}4750 \\
(87.47)\end{array}$ & $\begin{array}{c}5300 \\
(97.60)\end{array}$ & - \\
\hline 4. & Cost incurred by village trader & $\begin{array}{l}65.55 \\
(1.18)\end{array}$ & $\begin{array}{c}67.5 \\
(1.57)\end{array}$ & - \\
\hline 5. & Margin of the village trader & $\begin{array}{l}184.45 \\
(3.88)\end{array}$ & $\begin{array}{l}332.5 \\
(6.12)\end{array}$ & - \\
\hline 6. & Price received by wholesaler & - & $\begin{array}{l}5430 \\
(100)\end{array}$ & $\begin{array}{l}5620 \\
(100)\end{array}$ \\
\hline 7. & Cost incurred by wholesaler & - & $\begin{array}{l}74.12 \\
(1.36)\end{array}$ & $\begin{array}{l}82.12 \\
(1.45)\end{array}$ \\
\hline 8. & Margin of wholesaler & - & $\begin{array}{l}55.88 \\
(2.87)\end{array}$ & $\begin{array}{l}337.5 \\
(5.99)\end{array}$ \\
\hline 9. & Price paid by consumer & $\begin{array}{l}5430 \\
(100)\end{array}$ & $\begin{array}{l}5430 \\
(100)\end{array}$ & $\begin{array}{l}5620 \\
(100)\end{array}$ \\
\hline 10. & Total marketing cost & $\begin{array}{l}136.05 \\
(14.62)\end{array}$ & $\begin{array}{l}215.62 \\
(40.68)\end{array}$ & $\begin{array}{l}217.62 \\
(51.81)\end{array}$ \\
\hline 11. & Total marketing margin & $\begin{array}{r}184.45 \\
(19.83)\end{array}$ & $\begin{array}{l}388.38 \\
(73.27)\end{array}$ & $\begin{array}{c}337.5 \\
(80.35)\end{array}$ \\
\hline 12. & Price spread & $\begin{array}{l}930 \\
(100)\end{array}$ & $\begin{array}{r}530 \\
(100)\end{array}$ & $\begin{array}{l}420 \\
(100)\end{array}$ \\
\hline
\end{tabular}

In channel-III share of commission charges is high as compared to other expenditure Rs. 50/qtl which contribute (36.90) per cent, then transportation charges Rs.45/qtl i.e. (33.21) per cent, labour charges Rs.14/qtl (10.33) per cent, packing cost Rs. 12/qtl (8.85) per cent, losses Rs.9/qtl (6.64) per cent, and market fee Rs. 5/qtl and weighing charges Rs.0.50/qtl contributes (3.69) and (0.36) per cent of total marketing cost respectively.

\section{Marketing cost of ginger incurred by village trader}

Per quintal cost of marketing of ginger incurred by village trader were estimated and presented in table 4 . The total cost incurred by village trader accounted for Rs.65.55 and Rs. 67.5 per quintal in channel-I and channel-II respectively. In channel-I the share of expenditure in the total cost was the highest on transportation charges Rs.30/qtl which constitute (45.76) per cent closely followed by labour charges Rs.13/qtl i.e. (19.83) per cent, cost of storage Rs.12/qtl i.e.(18.30) per cent, and losses Rs. 10/qtl (15.25) per cent, weighing charges Rs. 0.40 i.e.(0.61) per cent, license charges Rs. 0.15 contributes (0.22) per cent in total marketing cost.

In channel-II transportation cost Rs.32/qtl contributes (47.40) per cent, labour charges Rs.14/qtl i.e. (20.74) per cent, losses Rs.10.5/qtl i.e.(15.55) per cent, storage cost 
was Rs.10/qtl(14.81) per cent, weighing charges Rs.0.40/qtl i.e. (0.59) per cent and license charges Rs.0.15/qtl (0.22) per cent cost was contributed in total cost of Marketing.

\section{Marketing cost of Ginger incurred by wholesaler}

Per quintal cost of marketing of ginger incurred by wholesaler channel-II and channel-III was estimated and presented in table 5. The result revealed that, cost of marketing incurred by wholesaler, was Rs 74.12 per quintal in channel-II and Rs.82.12 per quintal in channel-III. In channel-II contribution of transportation charges was high Rs.35/qtl which constitute (47.22) per cent of total marketing cost followed by contribution of labour charges Rs.16/qtl (21.58) per cent, losses Rs.12/qtl i.e. (16.18) per cent, Market fee Rs. 10/qtl (13.49) per cent, shop tax Rs.0.50/qtl i.e. (0.67) per cent, and license charges Rs.0.20/qtl means (0.26) per cent, electric charges Rs.0.42/qtl (0.56) per cent of total cost.

In channel-III share of transportation charges was high Rs.40/qtl i.e. 48.70 per cent, followed by labour charges Rs.17/qtl (20.70) per cent, losses Rs.14/qtl (17.04) per cent, Market fee Rs.10/qtl i.e. (12.17) per cent, shop tax Rs.0.50/qtl (0.60) per cent, license charges Rs.0.20/qtl i.e. (0.24) per cent electric charges Rs.0.42/qtl i.e. (0.56) per cent contribution in ginger marketing cost.

\section{Price spread in ginger marketing}

Marketing costs and margins of the Three marketing channels identified in the study area were worked out to assess the share of different functionaries involved and ultimately the producer's share in consumer's rupee and are shown in Table 6 . The results revealed That producer's share in consumer's rupee varied from channel to channel which was highest in channel-II 98.48 channel-I 98.43 per cent, and channel-III 97.39 per cent respectively.

In channel-I Net price received by producer was Rs. 4429.5; price received by producer from village trader was Rs. 4500 means 94.73 per cent. Then cost incurred by producer was Rs 70.5 i.e. 1.56 per cent. Price received by village trader was Rs. 4750 i.e. 87.47 per cent, cost of marketing incurred by village trader was Rs. 65.55 i.e. 1.18 per cent and market margin was Rs. 184.45 i.e. 3.88 per cent.

In channel-II Net Price received by producer Rs.4826, followed by cost incurred by producer was Rs. 74 i.e. 1.51 per cent, Price received by producer was Rs. 4900, In case of village trader price received Rs.5300 i.e. 97.60 per cent, cost incurred by village trader was Rs. 67.5 means 1.57 per cent and market margin was 332.5 i.e. 6.12 per cent. In case of wholesaler price received by wholesaler, cost incurred by wholesaler and market margin of wholesaler was Rs. 5430, Rs. 74.12 and Rs. 155.88 respectively.

In channel-III price received by producer, cost incurred by producer from wholesaler was 92.36 and 2.6 per cent; Then price received by wholesaler, cost incurred by wholesaler and market margin was Rs.5430, Rs. 82.12 i.e. 1.45 per cent and Rs. 337.5 i.e. 5.99 per cent respectively. The analysis of marketing cost and margins reveals that the total market margin highest in channel-II because there are large number of intermediaries in channel-II. Producer was getting higher share of consumer's rupee in channel-II than that of channel-I and channel-III. The price spread was lower, when it was sold directly to the wholesaler. Price spread was lower in channel-III as compare to channel-I and channel-II, it indicates that channel-III best for to sold ginger. 
In conclusion, Producer's share in consumer's rupee varied from channel to channel which was highest in channel-II 98.48 channel-I 98.43 per cent, and channel-III 97.39 per cent respectively.

The analysis of marketing cost and margins reveals that the total market margin highest in channel-II because there are large number of intermediaries in channel-II.

Producer was getting higher share of consumer's rupee in channel-II than that of channel-I and channel-III. The price spread in channel-I Rs. 930, channel-II Rs.530 and channel-III Rs. 420, when it was sold directly to the wholesaler, Price spread was lower in channel-III as compare to channel-I and channel-II, it indicates that channel-III best for to sold ginger.

\section{References}

Khose A.S, Chavan P.S., Nair B.G. (2014) Marketing of turmeric in Yavatmal district of Maharashtra. Hind Agricultural Research and Training Institute 9 (2): 268270.

Rajashekar and Kumar D. (2017) Cost and return of ginger in Bidar district of Karnataka an economic analysis. Journal of Pharmacognosy and Photochemistry. 6 (5): 472-475.

Papang J.S., Tripathi A.K. Anoop $\mathrm{M}$ and Choudhary B.B. (2016) Economics of Turmeric Marketing in Jaintia Hills District of Meghalaya. Indian Journal of Economics and Development 12 (1): 155160.

\section{How to cite this article:}

Shinde, S. E., R. D. Shelke and Bodakhe, G. M. 2020. Marketing of Ginger in Aurangabad District of Maharashtra. Int.J.Curr.Microbiol.App.Sci. 9(12): 555-561. doi: https://doi.org/10.20546/ijcmas.2020.912.067 